Brit. J. industr. Med., 1962, 19, 211.

\title{
ORAL CALCIUM DISODIUM VERSENATE IN TREATMENT OF LEAD POISONING
}

\author{
BY
}

J. D. Williams,* G. A. MATTHEWS, and A. W. JUDD

From the Department of Clinical Pathology, West Herts. and St. Paul's Hospitals, Hemel Hempstead, Herts.

(RECEIVED FOR PUBLICATION FEBRUARY 1, 1962)

A clinical trial of oral calcium disodium versenate (E.D.T.A.) in eight lead workers is described. A short course of versenate given while the men continued at work produced no side-effects. Complete overhaul of the processes and protective devices was made in the factory.

Clinical, biochemical, and haematological improvement followed the removal of up to $250 \mathrm{mg}$. lead in each case.

The mode of action and possible uses and abuses of oral versenate are discussed.

Despite the advances in the design of factories working with lead and the installation of protective devices, lead intoxication is still prevalent. Treatment of this condition has been considerably improved by the use of the calcium disodium salt of ethylene diamine tetra-acetic acid (E.D.T.A.) (Bessman, Ried, and Rubin, 1952).

This compound has the property of binding lead in a non-ionic form which is rapidly excreted in the urine. In this country reports have appeared on its intravenous use (Giles, Moore, and Still, 1955; Markus and Spencer, 1955; Travers, Rendle-Short, and Harvey, 1956; Leckie and Tompsett, 1958) and on its intramuscular use (Shrand, 1961).

Small factories working with lead compounds often have inadequate protective devices for their workers or minimal medical supervision. This can lead either to cases of frank lead poisoning or to excessive lead absorption by the men working with the compounds. Two small factories in this area were found to have inadequate safety precautions after several cases of lead poisoning had occurred among their workers. These cases were treated with calcium disodium ethylene diamine tetra-acetate (calcium disodium versenate $\dagger$ ) intravenously. All made good recoveries after the removal of large amounts of lead. Complete overhaul of the processes and protective devices was made in the factory.

In addition to the more severely affected men

*Present address: Department of Pathology, Edgware General Hospital, Edgware, Middlesex.

†Trade mark, Riker Laboratories, Loughborough, Leics. several others were found to have absorbed excessive amounts of lead to such a degree as to require treatment. As conditions at the factory were so rapidly improving and the men did not wish to stay off work, mainly for economic reasons, oral calcium disodium versenate и as used. The men were allowed to remain at the factory, under close medical supervision, working at the less hazardous processes.

\section{Methods of Investigation}

The assessment of the degree of lead absorption by lead workers was made on the results of haemoglobin, stippled cell, and reticulocyte estimations, the amount of lead in the urine and in the blood, the amount of coproporphyrin in the urine, and the presence of symptoms referable to lead. Haemoglobin was estimated by the alkaline haematin method and reticulocytes by Dacie's (1956) method. The method for determination of lead was essentially the same as that employed by King and Thompson (1961) which depends on the colour reaction with dithizone in a potassium cyanide-ammonium citrate buffer after preliminary wet oxidation of the urine with nitric and perchloric acids. Normal values are 40 to $50 \mu \mathrm{g}$. lead per litre of urine. Using special lowin-lead reagents + , very low blank levels were obtained. Copropcrphyrin was estimated and punctate basophils counted by the methods described by Lane (1949). Eight men showing an excessive degree of lead absorption were given a seven-day Essex.

tObtainable from Hopkin and Williams Ltd., Chadwell Heath, 
course of oral calcium disodium versenate, $4 \mathrm{~g}$. a day in divided doses. During treatment 24-hour samples of urine were collected each day for total lead determination and a semi-quantitative coproporphyrin test. In three men all specimens of urine passed on the first day of treatment were collected separately and analysed for lead content to see how quickly the versenate acted. In three men collections were continued for four days after treatment had been stopped to see for how long the action of versenate persisted. All the men except Case 3, who showed evidence of acute poisoning, continued at work during the treatment.

\section{Case Reports}

Case 1.-E.T.B., aged 40, worked as a wet mixer of lead paste for one year. His tests showed haemoglobin $12.0 \mathrm{~g} . / 100 \mathrm{ml}$. (81\% Haldane), stippled cells $3,100 /$ million red blood cells (R.B.C.), blood lead $130 \mu \mathrm{g} . / 100 \mathrm{ml}$., coproporphyrin $4+$, urine lead $300 \mu \mathrm{g}$./litre. One week after the course of versenate he showed haemoglobin 13.8 g. $/ 100 \mathrm{ml}$. (92\%), stippled cells $2,500 /$ million R.B.C. blood lead $140 \mu \mathrm{g} . / 100 \mathrm{ml}$., urine lead $180 \mu \mathrm{g}$./litre, coproporphyrin $1+$. During the course of versenate he excreted $15.1 \mathrm{mg}$. lead.

Case 2.-R.J.R. was a 60-year-old maintenance engineer who had been working in the lead works for eight years. A month before being seen he had overhauled the flues through which the lead dust was evacuated. He was complaining of weakness and tiredness. Haemoglobin 14.7 g. (99\%), stippled cells 3,900/million R.B.C., urine coproporphyrin $4+$, blood lead $130 \mu \mathrm{g}$. $/ 100$ $\mathrm{ml}$., urine lead $240 \mu \mathrm{g}$./litre. During a course of oral versenate he excreted $14.1 \mathrm{mg}$. lead. A week later he showed haemoglobin $14 \cdot 8$ g. $(100 \%)$, stippled cells $1,600 /$ million R.B.C., urine lead $180 \mu \mathrm{g}$./litre, coproporphyrin trace, blood lead $90 \mu \mathrm{g} . / 100 \mathrm{ml}$.

Case 3.-A.B. was a 34-year-old bachelor of rather untidy habits who had been working with lead compounds for three months. He was feeling tired and was rather unsteady on his feet. He had multiple neurofibromatosis. Laboratory tests showed haemoglobin $8.3 \mathrm{~g} . / 100 \mathrm{ml}$. (56\%), reticulocytes $3.0 \%$, stippled cells $17,700 /$ million R.B.C., urine lead $940 \mu \mathrm{g}$./litre, blood lead $140 \mu \mathrm{g} . / 100 \mathrm{ml}$., coproporphyrin $4+$. The blood film showed numerous stippled cells, many of which were shrunken and poikilocytotic. There were occasional normoblasts. Bilirubin $0.9 \mathrm{mg} . / 100 \mathrm{ml}$.

$\mathrm{He}$ was treated with oral versenate in hospital and excreted $23.8 \mathrm{mg}$. of lead in seven days. Coproporphyrin was still high. His blood count at this time showed a great increase in stippled cells $(56,000)$ and reticulocytes $(9 \cdot 4 \%)$; haemoglobin was $9 \cdot 2 \mathrm{~g} . / 100 \mathrm{ml}$. (62\%). He could not be detained in hospital any longer and remained at home for two weeks. At the end of this time his urine lead was averaging $400 \mu \mathrm{g}$./litre and coproporphyrin $4+$, and he re-entered hospital for a course of intravenous versenate. His haemoglobin was $11.5 \mathrm{~g} . / 100 \mathrm{ml}$. (78\%).
He received 2 g. versenate intravenously each day for five days in $500 \mathrm{ml}$. of saline.

$\mathrm{He}$ excreted $25.4 \mathrm{mg}$. of lead in six days. One week later his assessment showed haemoglobin $14.8 \mathrm{~g} . / 100 \mathrm{ml}$. $(100 \%)$, blood lead $60 \mu \mathrm{g} . / 100 \mathrm{ml}$. , urine lead $160 \mu \mathrm{g}$./litre, coproporphyrin $1+$. Stippled cells absent.

Case 4.-T.G., a 40-year-old Pole, worked in various lead works for 12 years with no complaints. Haemoglobin 15.5 g./100 ml. (105\%), stippled cells $1,800 /$ million R.B.C., blood lead $170 \mu \mathrm{g} . / 100 \mathrm{ml}$., urine lead 540 $\mu \mathrm{g}$./litre, coproporphyrin $4+$. He excreted $11.9 \mathrm{mg}$. lead during his seven-day course of treatment. Later he showed haemoglobin $16.5 \mathrm{~g} . / 100 \mathrm{ml}$. (112\%), reticulocytes $2.6 \%$, stippled cells $2,100 /$ million R.B.C., urine lead $220 \mu \mathrm{g}$./litre, blood lead $120 \mu \mathrm{g}$./100 ml., coproporphyrintrace.

Case 5.-A.G.C., a 38-year-old man, was one of three brothers working with lead compounds. The other two had been treated six months previously with intravenous versenate for lead poisoning. A.G.C. presented with weakness and constipation. His haemoglobin was $14.8 \mathrm{~g} . / 100 \mathrm{ml}$. ( $100 \%)$, reticulocytes $2 \cdot 3 \%$, urine lead $140 \mu \mathrm{g}$./litre, and his urine contained a small amount of coproporphyrin. He received $4 \mathrm{~g}$. versenate daily for one week and excreted $8 \mathrm{mg}$. of lead in his urine during this time. There was marked improvement in symptoms. Urine lead fell to $70 \mu \mathrm{g}$./litre; haemoglobin remained the same. Reticulocytes were $1.7 \%$. He continued at work, but three months later his haemoglobin was $13.6 \mathrm{~g} . / 100$ ml., reticulocytes $3.4 \%$, stippled cells $10,000 /$ million R.B.C., urine lead $210 \mu \mathrm{g}$./litre, blood lead $120 \mu \mathrm{g}$./100 ml., coproporphyrin $1+$. During a repeated course of versenate (present series) he excreted $12.6 \mathrm{mg}$. lead, and the haemoglobin rose to $14.5 \mathrm{~g} . / 100 \mathrm{ml}$. $(98 \%)$, reticulocytes $2.5 \%$, stippled cells $13,200 /$ million R.B.C., blood lead $90 \mu \mathrm{g}$./100 ml., urine lead $120 \mu \mathrm{g}$./litre, coproporphyrin $1+$.

Cases 6, 7, and 8.-These three cases worked in a small accumulator factory. E.A.K., age 59, for one and a half years, W.F., age 57, for nine years, and E.C.B., age 55, for three months. E.A.K. had episodes of constipation; the others were symptom-free. Laboratory findings were as follows:

Case 6.-E.A.K., haemoglobin $12.8 \mathrm{~g} . / 100 \mathrm{ml}$. (87\%), stippled cells $12,000 /$ million R.B.C., urine lead 240 $\mu \mathrm{g}$./litre, blood lead $130 \mu \mathrm{g} . / 100 \mathrm{ml}$., coproporphyrin $1+$. Oral versenate for seven days, lead excretion $15.7 \mathrm{mg}$. Later haemoglobin 13.9 g./100 ml. (94\%), stippled cells 9,100/million R.B.C., urine lead $240 \mu \mathrm{g}$./litre, blood lead $120 \mu \mathrm{g} . / 100 \mathrm{ml}$., coproporphyrin trace.

Case 7.-W.F., haemoglobin 10.6 g. $/ 100 \mathrm{ml}$. (72\%), stippled cells 5,000/million R.B.C., urine lead $600 \mu \mathrm{g}$./litre, coproporphyrin $1+$, blood lead $1.0 \mu \mathrm{g} . / 100 \mathrm{ml}$. On oral versenate treatment seven-day lead excretion $13.7 \mathrm{mg}$. Later haemoglobin $12 \cdot 3 \mathrm{~g} . / 100 \mathrm{ml}$. (83\%), stippled cells 4,600/million R.B.C., urine lead $240 \mu \mathrm{g}$./litre, coproporphyrin trace, blood lead $80 \mu \mathrm{g} . / 100 \mathrm{ml}$.

Case 8.-E.C.B., haemoglobin $12.6 \mathrm{~g} . / 100 \mathrm{ml}$. (85\%), stippled cells 4,200/million R.B.C., urine lead $300 \mu \mathrm{g}$./litre, 


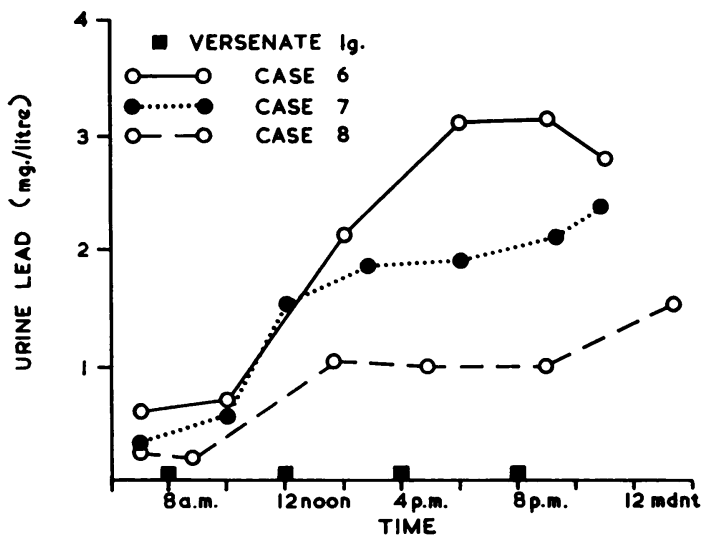

FIG. 1.-Oral versenate is rapidly absorbed causing a big rise in lead excretion within six hours.

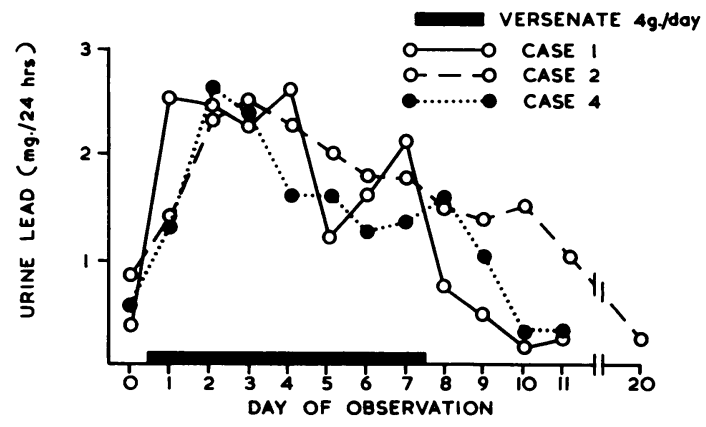

FIG. 2.-Shows a variation in effect of oral versenate. In Cases 1 and 4 the urine lead content fell rapidly on withdrawal of the tablets. In Case 2 it was still over $1 \mathrm{mg}$. $/ 24$ hours four days after treatment was stopped.

coproporphyrin $4+$, blood lead $110 \mu \mathrm{g} . / 100 \mathrm{ml}$. On treatment with oral versenate, seven-day lead excretion was $7.6 \mathrm{mg}$. Later haemoglobin $12.4 \mathrm{~g} . / 100 \mathrm{ml}$. (84\%), stippled cells 5,800/million R.B.C., urine lead $100 \mu \mathrm{g}$./litre, coproporphyrin nil, blood lead $1 \cdot 1 \mu \mathrm{g} . / 100 \mathrm{ml}$.

\section{Results}

Oral versenate caused lead to be rapidly excreted in the urine. The lead content of the urine increased $500 \%$ within five hours (Fig. 1). The daily excretion of lead rose to a maximum on the second day in five cases, the third day in one, and the fourth day in two. The concentration of lead in the urine rose to five to 11 times the base-line concentration. In two of the three men in whom extended collections of urine were made the output of lead continued at a decreasing rate up to the third post-treatment day, when the levels were 350 and $200 \mu \mathrm{g}$./day respectively. In the third man the excretion rate was still high at

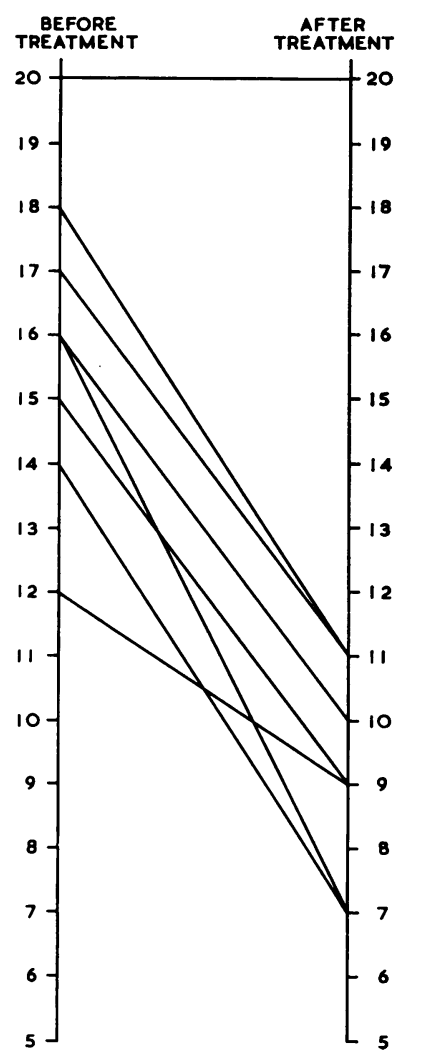

FIG. 3.-Chart showing the improvement in laboratory findings after treatment. On the left are the numbers of points for each man before treatment and on the right the numbers for abnormal biochemical and haematological findings of points after treatment.

$1,066 \mu \mathrm{g}$. (880 $\mu \mathrm{g}$./litre) on the eleventh day but by the twentieth day it had fallen to $180 \mu \mathrm{g}$./litre (Fig. 2). The total lead excretion during the seven days of treatment varied from 7.6 to $23.8 \mathrm{mg}$., averaging $14 \cdot 32 \mathrm{mg}$. lead per man.

Seven of the eight men showed a rise in haemoglobin level averaging $1.0 \mathrm{~g}$. $\%$ (range 0.1 to $1.8 \mathrm{~g}$.), and one showed a fall of $0 \cdot 2 \mathrm{~g}$. $\%$.

In four the stippled cell count was lower at the end of treatment, but in the others it was higher. The urine lead concentration was lower after treatment than before in seven out of the eight men. Coproporphyrin levels tended to rise early in treatment, while large amounts of lead were being excreted, but fell rapidly later. Blood lead levels fell in five patients, remained the same in one, and rose in one.

Symptomatically the improvement was marked. One patient (Case 4) who felt "fine" before treatment felt "fine" after it. All the others volunteered feeling 
TABLE

CRITERIA FOR CALCULATING NUMBER OF POINTS FOR ABNORMAL BIOCHEMICAL AND HAEMATOLOGICAL FINDINGS

\begin{tabular}{|c|c|c|c|c|c|}
\hline & 0 & 1 & 2 & 3 & 4 \\
\hline $\begin{array}{l}\text { Coproporphyrin } \\
\text { Stippled cells } / 1,000 \text { R.B.C. } \\
\text { Blood } \mu \mathrm{g} . \mathrm{Pb} / \mathrm{ml} \text {. } \\
\text { Urine } \mu \mathrm{g} . \mathrm{Pb} / \text { litre } \\
\text { Haemoglobin } \%\end{array}$ & $\begin{array}{l}0 \\
0-0 \cdot 9 \\
0-0 \cdot 2 \\
0-79 \\
>102\end{array}$ & $\begin{array}{l}\mathrm{Tr}+ \\
1 \cdot 0-1 \cdot 4 \\
0 \cdot 3-0 \cdot 5 \\
80-159 \\
96-100\end{array}$ & $\begin{array}{c}++ \\
1 \cdot 5-1 \cdot 9 \\
0 \cdot 6-0 \cdot 8 \\
160-239 \\
90-94\end{array}$ & $\begin{array}{c}+++ \\
2 \cdot 0-2 \cdot 9 \\
0 \cdot 9-1 \cdot 1 \\
240-319 \\
84-88\end{array}$ & $\begin{array}{l}++++ \\
\quad>3 \\
\quad>1 \cdot 2 \\
>320 \\
<82\end{array}$ \\
\hline
\end{tabular}

far more energetic, less tired, and having freer bowel actions. Case 3 had slight vomiting and diarrhoea after leaving hospital but the others reported no side-effects.

In Fig. 3 we have expressed graphically the improvements in the patients after treatment with oral versenate. King and Thompson (1961) when measuring the amount of lead absorption in car workers, gave the result of each test a number of points depending on its deviation from the normal. A normal result scored no points, a minor abnormality one, a gross abnormality four, and intermediate grades two or three points. The criteria they used are reproduced in the Table, and although the stippled cell and blood lead levels they used are rather low, we have adopted the same criteria to assess our results. Seven of the men showed a fall in the number of points they scored before and after treatment, the average fall being six points. Only in Case 3 was the same number of points scored before and after the course of treatment.

\section{Discussion}

We have confirmed that versenate taken orally causes a rapid rise in urinary lead excretion, maintains the excretion of lead, and that the effect persists in some cases for several days after treatment finishes. It also has a beneficial effect on the patient and his disease.

Previous reports on lead excretion in the urine after oral versenate follow a similar but not so uniform a pattern as in our cases. Sidbury, Bynum, and Fetz (1953) obtained increased excretions in three out of four patients, Bradley and Powell (1954) in three out of five. Bell, Gilliland, Boland, and Sullivan (1956) obtained excretion levels up to $4 \mathrm{mg}$. a day in three cases, one of whom had already received intravenous therapy with versenate. Shiels, Thomas, and Kearley (1956) in a careful study on six hospital patients obtained rises in levels up to 20 times those obtained before treatment.

The improvement in well-being of men on oral E.D.T.A. at work was shown by Manville and Moser (1955) and seven men treated for three weeks were freed of coproporphyrinuria. Cotter (1954) also recorded improvement.
One question mentioned in almost all previous papers on the use of oral versenate is the possibility of the versenate combining with lead in the lumen of the bowel with subsequent absorption and excretion into the urine. In other words, is the versenate really removing lead from the tissues or is it merely altering the route of excretion? The evidence for the latter view comes from animal studies.

Most of the lead excreted from lead-poisoned sheep is via the bile-ducts into the intestine, and only $20 \%$ of the excretion is via the urinary tract (Blaxter and Cowie, 1946). In lead-poisoned rabbits oral versenate shifts the excretion of lead from the faeces to the urine (Rieders, 1954). Furthermore Mosey et al. (Cited by Sidbury et al., 1953) have shown that the lead chelate of E.D.T.A. is rapidly absorbed from the upper gastro-intestinal tract.

In humans, however, a rise in faecal lead on oral versenate has been reported by Bell et al. (1956) and by Shiels et al. (1956), both working with hospital patients who were removed from any opportunity of swallowing or inhaling more lead. Bell also reports a rapid fall in faecal lead on intravenous versenate due, no doubt, to the rapid excretion of E.D.T.A. into the urine carrying with it chelated lead and by-passing the biliary tract.

Cases 6,7 , and 8 show that it is not recently ingested lead that combines with versenate in the gastro-intestinal tract to be absorbed and then re-excreted in the urine. Treatment was started on a Saturday and the men returned to work on a Monday. The peak of excretion in all cases was on the Sunday and there was no significant rise when they returned to work. The excretion rates continued to fall, presumably in parallel with the available stores of lead in the tissues.

Oral versenate is rather poorly absorbed from the gastro-intestinal tract. Foreman and Trujillo (1954) who gave $\mathrm{C}^{14}$ labelled E.D.T.A. orally to volunteers, found only about $5 \%$ of the total dose in the urine. However, it is probable that enough is absorbed to be effective because Pagnotto, Elkins, and Bayka (1958) showed that after oral administration in normal subjects free versenate was present in the urine in sufficient concentration for each litre of 
urine to bind $7 \mathrm{mg}$. lead in vitro. Leckie and Tompsett (1958) obtained high excretions of lead when using only $50 \mathrm{mg}$. of versenate intravenously, one case excreting $1,430 \mu \mathrm{g}$. lead in the 48 hours following a single dose.

Whatever the exact mechanism is, the undoubted improvement of the patient suggests that the net result is a removal of lead from the tissues.

Kehoe (1955) drew attention to the possible abuses of oral versenate and expressed fears lest the tablets were used to mask deficiencies in the protective equipment and the industrial processes. A simple prophylactic against lead poisoning has a great attraction for manufacturers when set against the often large outlay involved in installing protective devices, but it seems quite unjustifiable to expose men to the known hazards of lead compounds and at the same time to expose them to the yet unknown hazards of prolonged versenate therapy. For this reason we feel that the use of oral versenate should be limited. We have used it to treat cases of mild lead poisoning only when the processes at which the poisoning occurred have been modified or the men have been moved to a less hazardous process. When used in this way we have found it to be very effective in promoting lead excretion with the minimum of disturbance to the patient.

The output of lead in the urine following the intravenous use of versenate has been used in diagnosing excessive lead absorption (Leckie and
Tompsett, 1958). It is possible that oral versenate may have a similar diagnostic use.

Oral versenate appears to be a useful supplementary measure in the medical supervision of people who run the risk of absorbing lead.

We are indebted to Dr. A. R. Thompson and Mr. A. H. Waldron of Vauxhall Motors, Luton, for the blood lead determinations. We wish to thank Dr. P. J. R. Challen of the Occupational Hygiene Service, Slough, and Dr. J. H. Harrison who referred the cases to us, and Dr. A. R. Kelsall under whose care Case 3 was admitted.

\section{REFERENCES}

Bell, R. F., Gilliland, J. C., Boland, J. R., and Sullivan, B. R. (1956), A.M.A. Arch. industr. Hlth, 13, 366

Bessman, S. P., Ried, H., and Rubin, M. (1952). Med. Ann. D.C., 21. 312.

Blaxter, K. L., and Cowie, A. T. (1946). Nature (Lond.), 157, 588.

Bradley, J. E., and Powell, A. M. (1954). J. Pediat., 45, 297.

Cotter, L. H. (1954). J. Amer. med. Ass., 155, 906.

Dacie, J. V. (1956). Practical Haematology, 2nd ed., pp. 23 and 30. Churchill, London.

Foreman, H., and Trujillo, T. T. (1954). J. Lab. clin. Med., 43, 566.

Giles, H.McC.. Moore, C. T. and Still, B. M. (1955). Lancet, 1, 183.

Kehoe, R. A. (1955). J. Amer. med. Ass., 157, 341.

Kehoe, R. A. (1955). J. Amer. med. Ass., 157, 341.

King, E., and Thompson, A. R. (1961). Ann. occ

Lane, R. E. (1949). Brit. J. industr. Med., 6, 125.

Manville, I. A., and Moser, R. (1955). A.M.A. Arch. industr. Hlth, $12,528$.

Markus, A. C., and Spencer, A. G. (1955). Brit. med. J., 2, 883.

Pagnotto, L. D., Elkins, H. B., and Bayka, I. (1958). A.M.A. Arch. industr. Hith, 17, 29.

Rieders, F. (1954). Fed. Proc., 13, 397.

Shiels, D. O., Thomas, D. L. G., and Kearley, E. (1956). A.M.A. Arch. industr. Hlth, 13, 489.

Shrand, H. (1961). Lancet, 1, 310 .
Sidbury, J. B., Jnr., Bynum, J. C., and Fetz, L. L. (1953). Proc. Soc.

exp. Biol. (N.Y.), 82, 226.
Travers, E., Rendle-Short, J., and Harvey, C. C. (1956). Lancet, 2. 113 . 